\title{
許 溲
}

\section{フランスにおける臨界安全性研究の現状*}

\author{
Recent Progress in Criticality Safety Research in France
}

By P.R. LÉCORCHÉ**

核燃料の処理, 取扱いにおける臨界安全性を確保す るためには，取り扱われる核燃料の種類, 組成, 用いら れる装置や容器類の形状, 寸法, 配置などさまさまな条 件に括ける臨界データが必要であり，また安全対策を 考える上からは種々の状況下で起りうる臨界暴走事故 の規模や特性を理解しておくことが望ましい。このよ らな臨界安全性の基礎に関する実験的研究は, フラン スにおいては1958年頃からサクレー研究所で“Proserpine”や“Alecto”と呼ばれる水溶液系臨界実験装置を 用いて行われてきたが，1963年にはパリーの南東約 $300 \mathrm{~km}$ にある古都 Dijon の北方郊外に Valduc 臨界
実験所(Station de Criticite) が建設され，3つの臨界 実験セルに括いて活発な実験研究が続行されている。 特に1968年11月からは CRAC (Conséquences Radiologique d'un Accident de Criticité) と呼ばれる核燃料 水溶液系の臨界暴走実験力3開始され，現在までに19回 の害験が行われた。以下にこの Valduc 臨界害験所に おける実験研究の現状を紹介しよ5。

\section{I . Valduc 臨界実験所の施設}

第 1 図は Valduc 臨界実験所の建屋内実験室配置図 である。天井までの高さ約 $10 \mathrm{~m}$ の臨界実験用セルが 3

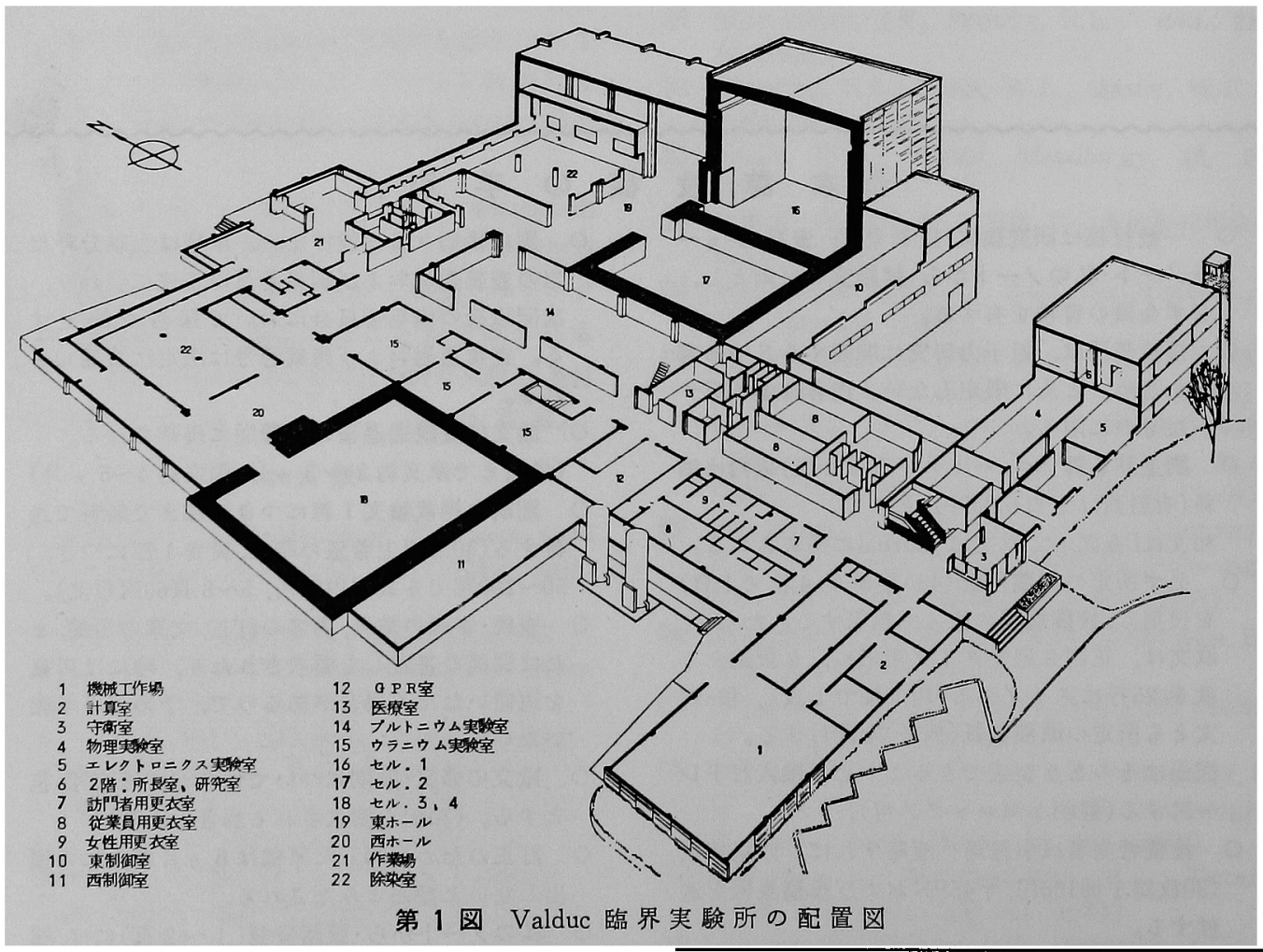

つあって，その床面積はセル 1 およびセル 2 はおのお の $9 \mathrm{~m} \times 12 \mathrm{~m}$ ，七ル 3 は $19 \mathrm{~m} \times 12 \mathrm{~m}$, 遮蔽壁の厚さ
* 1969年12月18日赤坂三会堂ビルホールにて講演。 （座長 東大 山本 寬氏）

** Service d'Etudes de Criticité, D.P.S.R., CEA. 
俚側壁が $1.45 \mathrm{~m}$ ，天井が $0.70 \mathrm{~m}$ となっている。空気の 放射能污染を防止するため，実験はセル内に組み立て られた気密室(ケーンン)の中で行われ，さらに核燃料 溶液の操作は年ローブ・ボックスを用いて行う。付带 設備としては，実験に用いるPuや高濃縮Uの溶液を精 製,調製する化学処理実験室, 各種物理椡定室, 除染設 備, エレクトロニクス・ショップ, 機械工作室, 放射線管

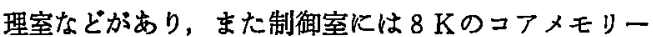
をるつデータ処理用小型電子計算機が備兄てあり，才 ンラインのデータ処理が行われている。実験セル内で は種々の目的に岕じた臨界実臨装置が組み立てられ， 一部はすでに実験を終了して解体されたるのるある が，主な装置としては次のようなるのがある。

(1) “B”装置：第 2 図に示すように $3.2 \mathrm{~m} \times 2.1 \mathrm{~m}$ $\times 1.5 \mathrm{~m}$ の水槽内で，水その他の反射体に囲まれた 1

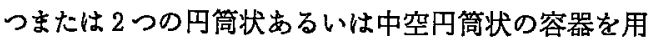
いて Pu 溶液の臨界実験が行点る装置て，セル 2 内に 設置されている。Pu 溶液の詝槽，ポンプなどは床下実 験室のグローブ・ボックス内に収めてある。

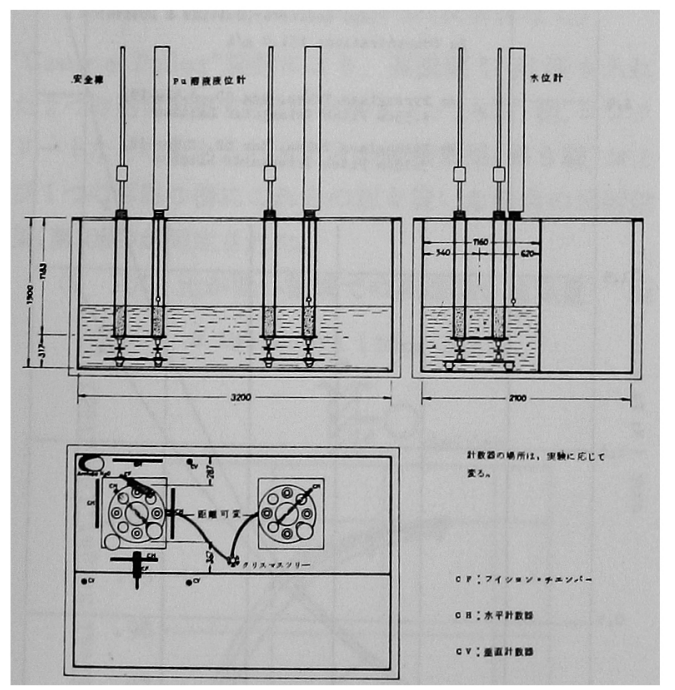

第 2 図“B”装置による2つの中空 円筒間の相互干涉赛驗

(2) “Castor-et-Pollux”装置：双子座と名づけられ たこの装置はセル1内に設備されており，第3图で気 密ヶーソン内の左側に見られる。直径 $30 \mathrm{~cm}$ の円筒容 器 2 個の間隔を $220 \mathrm{~cm}$ まで自由に変えることができ， $2 つ$ 容器の相互干涉実験や，種々の材料による中性 子遮萭あるいは反射効果の実験に用いられる。

(3) “D”装置: 第 3 図で“Castor-et-Pollux”装置の 右に示されている装置で, 直径 $35 \mathrm{~cm}$ の円筒容器を用

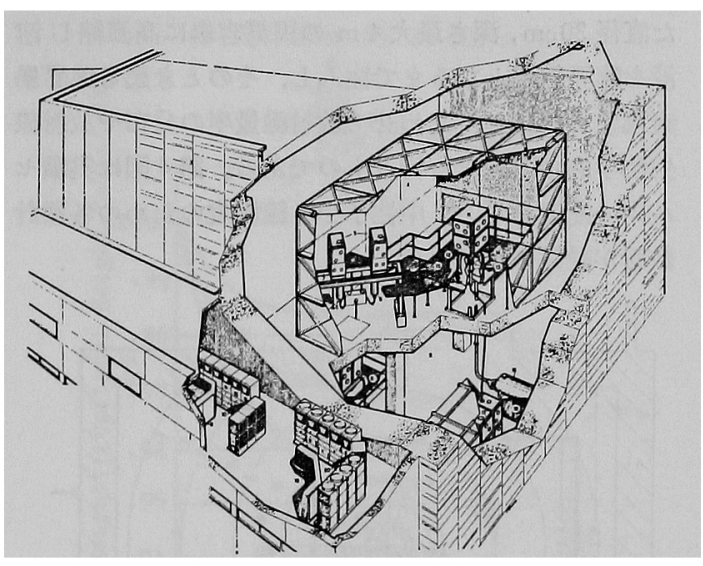

第3図“Castor-et-Pollux”および“D”装置

い，B入りパイレックスガラス管を格子状に配列した 場合の $\mathrm{Pu}$ 溶液の臨界量の測定や，Pu 溶液中に未溶 解の燃料ビンが並んでいる場合の臨界実験などが行わ れる。

（4）“CRAC”実験装置：セル3，44仕切り壁を取り 外して大実験セルとし，その中に組み立てられた気密 ケーソン内で水溶液系の臨界暴走実験 CRAC が実施 されている。この装置は写真 1 K見られるような特殊 のグローブ・ボックス(内容積約 $8 \mathrm{~m}^{3}$ )の中に設けられ

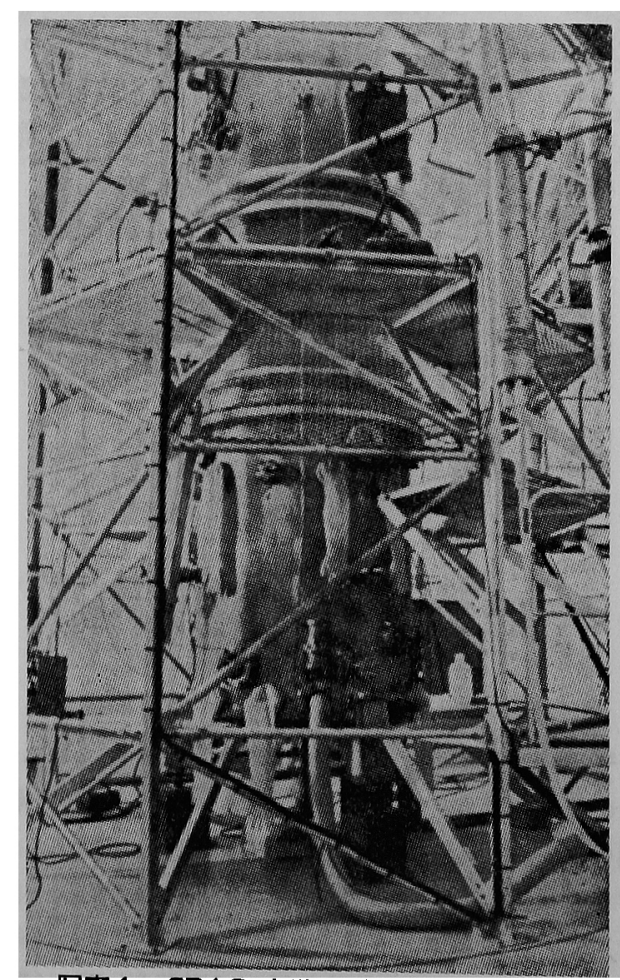

写真 1 CRAC 実験用グローブ・ボックス 
た直径 $30 \mathrm{~cm}$, 深さ最大 $4 \mathrm{~m}$ の円筒容器に高濃縮 $\mathrm{U}$ 溶 液を臨界超過となるまで注入し，そのとき起る臨界暴 走現象を観測し，あわせて放射線量率の分布や放射線 生物学的な研究をる行 5 すのである。第 4 図は実験セ ル内の配置を示し，中性子や $\gamma$ 線測定のための各種計 数管が設置されている。

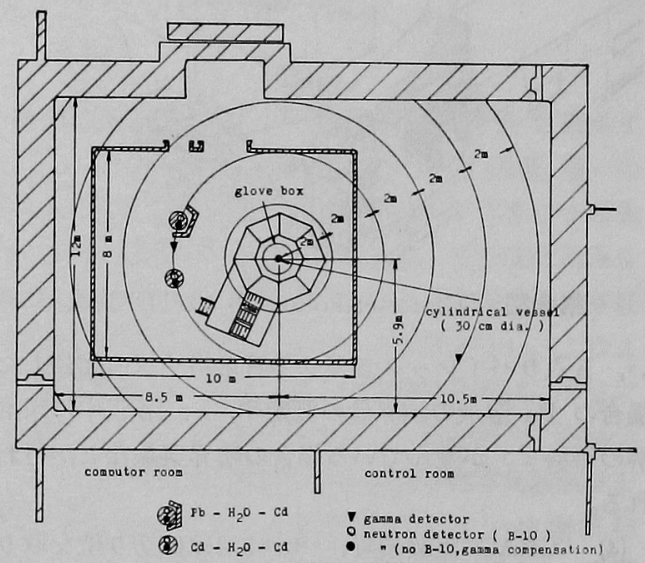

第 4 図“CRAC”実験配置図

\section{II . 臨界実験装置による実験結果の例}

（1） ${ }^{240} \mathrm{Pu}$ 含有量が $\mathrm{Pu}$ の臨界量に及注す効果: ${ }^{240} \mathrm{Pu}$ の含有率が1.5, 3.11, 4.23, 6.93おおび を用い，水反射体付きの中空円筒または円筒状容器に 入れた $\mathrm{Pu}$ 溶液の臨界量が $\mathrm{Pu}$ 濃度の関数として測定 された。(第 5図)

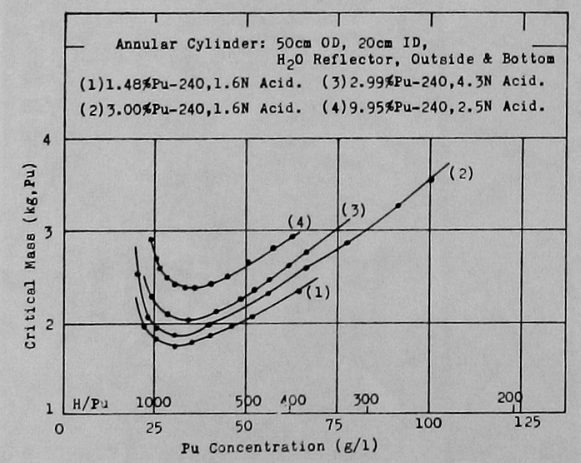

第 5 図種々の ${ }^{240} \mathrm{Pu}$ 含有率の $\mathrm{Pu}$ 溶液臨界量

${ }^{240} \mathrm{Pu}$ 含有率が高いと $\mathrm{Pu}$ の臨界量は大きくなるが， その増加割合は ${ }^{241} \mathrm{Pu}$ の影響もあって ${ }^{240} \mathrm{Pu}$ 含有率が 高いはど減少してゆく。（第 6 図）

（2）非均質中性子吸収材の効果：Pu 溶液の中に B入りパイレックスガラス管を格子状に配列した場合 の Pu 臨界量が“D”装置を用いて測定された。（第 7

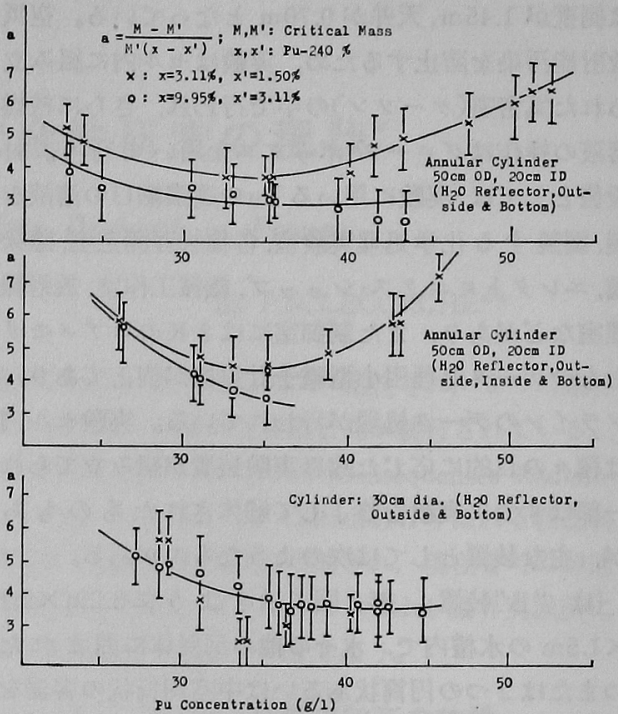

第 6 図 ${ }^{240} \mathrm{Pu}$ 含有率の $\mathrm{Pu}$ 臨界量に及ぼす効果

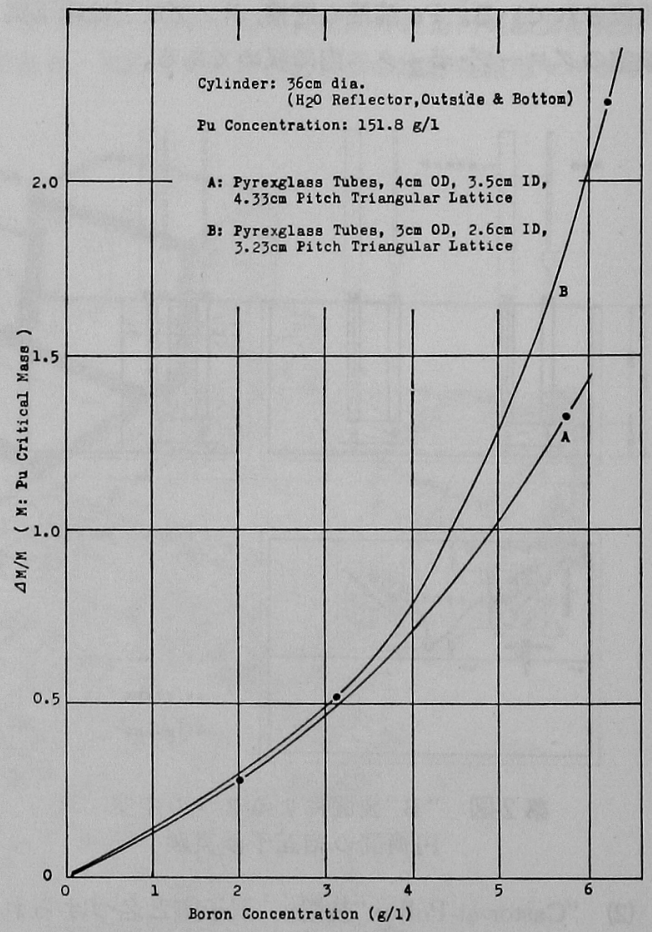

第 7 図 Bの添加による $\mathrm{Pu}$ 溶液臨界量の増加 図)

（3） 円筒容器の相互干涉：反射体のない場合に $2 \sim 4$ 本の円筒容器(直径 $30 \mathrm{~cm}$ )を配列したときの容 器間の間隔と $\mathrm{Pu}$ 溶夜の臨界高さとの関係が“ $\mathrm{B}$ ”装置 を用いて測定された。(第 8 図)

（4）種々の材料による中性子遮蔽および反射効果 


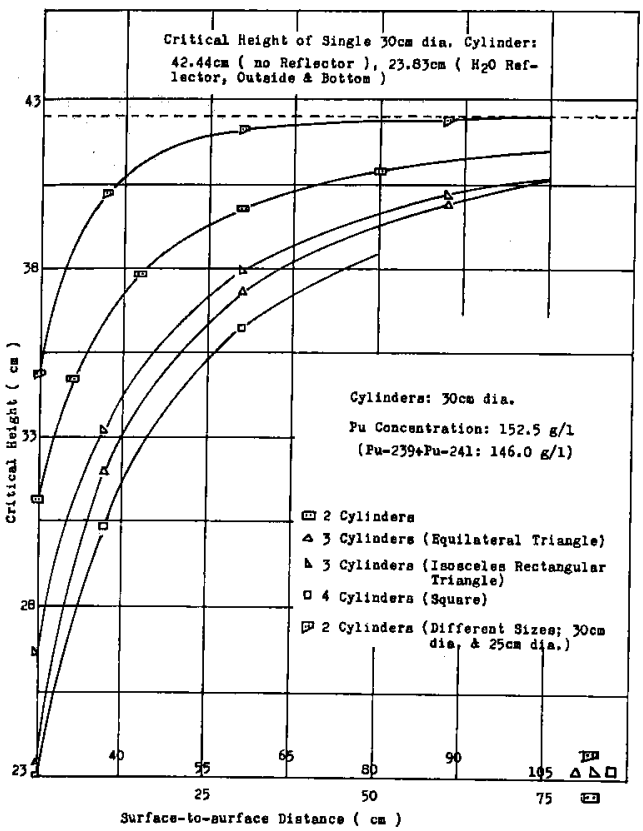

第 8 图 円筒容器の相互干涉(反射体なし)

“Castor-et-Pollux”装置により，高濃縮 U 溶液を入れ た 2 つの筒容器の間にパラフィン, 木材, 鉛, コンク リートなどの板を入れたときの遮蔽効果(第 9 図)扎 び1つの容器の傍にこれらの板を置いた場合の反射効 果(第10図)が測定された。

（5） H/U 比が低い領域での高濃縮U臨界量：低

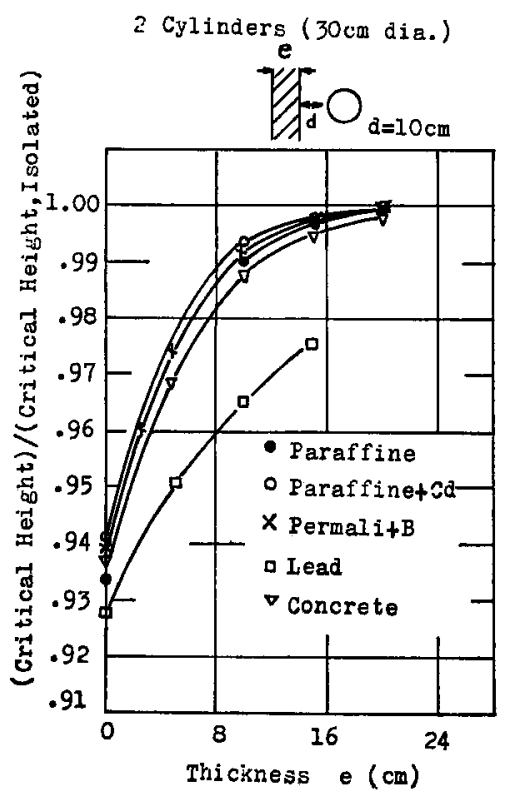

第 9 図各種材料による遮蔽効果
1 Cylinder ( $30 \mathrm{~cm}$ dia.)

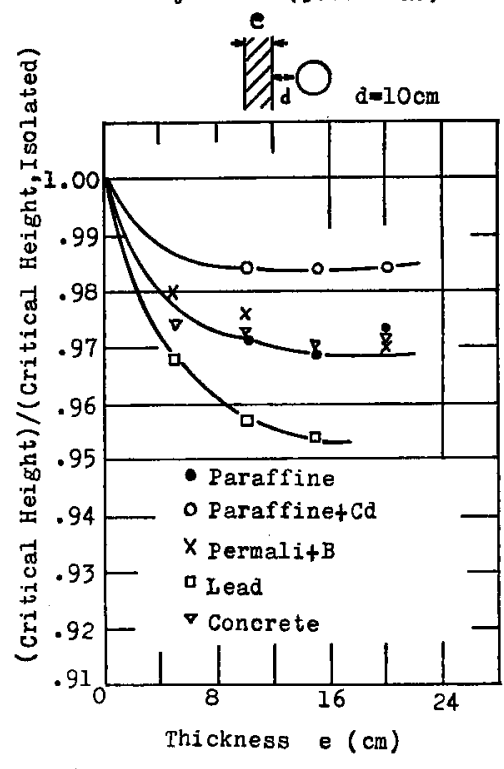

第10図各種材料に上る反射効果

減速度(H/U $\leq 20) の$ 領域での93\%濃縮Uの臨界量を検 討するため, $\mathrm{UF}_{6}-\mathrm{HF}$ 溶液を用いてモネル製球型容器 に上る臨界実験(水反射体付き)が行われ，その結果は 第11図の曲線(1)に示されている。第12図はこの場合の 実験之計算の比較で，実験には物性值中寸法上の誤差 をまた計算值にはモンテカルロ法を用いた場合の流 計的誤差が示されている。DSN輸送理論コードが実験 とよい一致を示したので, これを用いて $\mathrm{UO}_{2} \mathrm{~F}_{2}-\mathrm{H}_{2} \mathrm{O}$

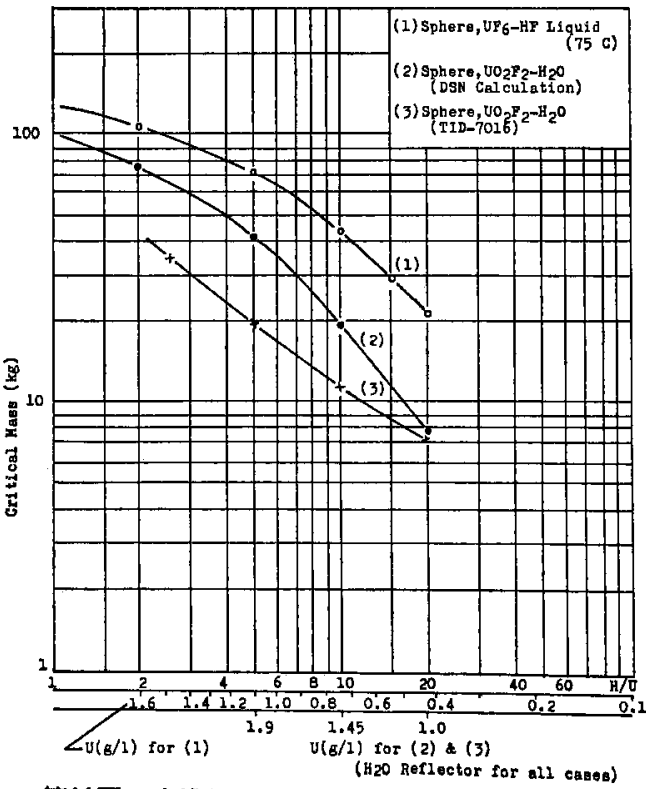

第11图高濃縮U臨界量(H/U 比が低い範围) 
系について計算し，TID-7016 の值と比較した結果が 第11図の曲線(2)と(3)である。

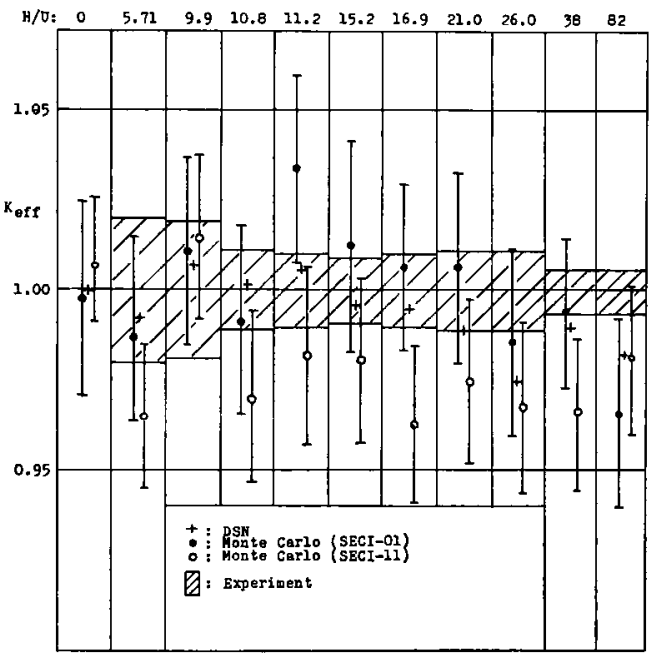

第12図実験と計算の比較 $\left(\mathrm{UF}_{8}-\mathrm{HF}\right.$ ， 球型，水反射体付き）

\section{III. 臨界暴走実験“CRAC”}

1968年11月に開始されたこの実験は，現在 Valduc 実験所に括ける主要な研究計面となっている。その目 的は，核燃料水溶液系での臨界事故の特性を調べるこ とにあり, 臨界暴走時の出力, 温度, 压力の変化などを
測定記録するのみならず，実験セル内外の線量測定，臨 界警報系の試験, 生物試料の照射実験などす含め心計 画である。すで行われた19回の実験の主要な条件と 測定結果は第 1 表に示されて拈り，また代表的な実験 に拈ける出力変化の様子は第13図に示されている。

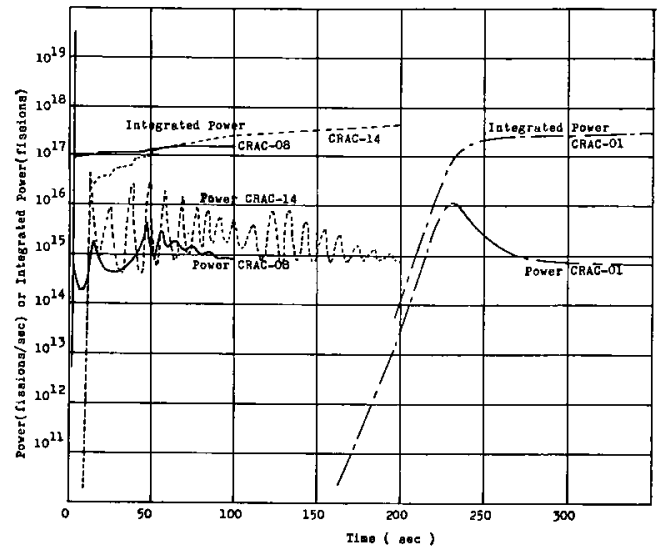

第13图 CRAC 実駼の例(出力の時間変化)

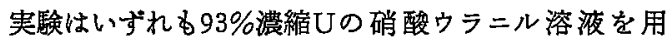
い，U濃度はお上そ $50 \sim 400 \mathrm{~g} / /$ の範囲にわたってお り，溶液の濃度(したがって臨界液位)，溶液の注入速 度(したかっって反応度の添加速度)，および臨界を超克 て注入する液量(したがって全添加超過反度度)を種々 変化させて実験が行われた。データ処理にはオンライ

第 1 表 CRAC 実験リスト

\begin{tabular}{|c|c|c|c|c|c|c|c|c|c|c|}
\hline $\begin{array}{c}\text { 実験番号 } \\
\text { CRAC }\end{array}$ & $\begin{array}{c}{ }^{235} \mathrm{U} \text { 濃度 } \\
(\mathrm{g} / \mathrm{l})\end{array}$ & $\begin{array}{c}\text { 臨界液位 } \\
(\mathrm{cm})\end{array}$ & $\mid \begin{array}{c}\text { 注入終了 } \\
\text { 時液位 } \\
(\mathrm{cm})\end{array}$ & \begin{tabular}{|} 
全添加超過 \\
反応度 \\
(pcm)
\end{tabular} & $\begin{array}{c}\text { 注入速度 } \\
(l / \mathrm{hr})\end{array}$ & $\mid \begin{array}{c}\text { 第 } 1 \text { の出力 } \\
\text { ピークまて } \\
\text { の時間市 } \\
\text { (sec) }\end{array}$ & \begin{tabular}{|c|} 
注入終了 11 \\
までの時間 \\
$(\mathrm{sec})$
\end{tabular} & $\begin{array}{l}\text { 全積算出 } \\
\text { 力开 } \\
\text { (fiss.) }\end{array}$ & $\begin{array}{l}\text { 出力最高 } \\
\text { 値Itt } \\
\text { (fiss./sec) }\end{array}$ & $\begin{array}{c}\text { 用いた } \\
\text { 容器の } \\
\text { 深さ } \\
(\mathrm{m})\end{array}$ \\
\hline $\begin{array}{l}01 \\
02 \\
03 \\
04 \\
05\end{array}$ & $\begin{array}{c}48.5 \\
48 ; 58 \\
48.6 \\
48.15 \\
56.9\end{array}$ & $\begin{array}{l}194^{\mathrm{a})} \\
208^{\mathrm{a})} \\
184.2^{\mathrm{a})} \\
190^{\mathrm{a})} \\
69.05^{\mathrm{b})}\end{array}$ & $\begin{array}{l}372.5 \\
279 \\
370.8 \\
346 \\
100.2\end{array}$ & $\begin{array}{r}540 \\
\sim 1,000 \\
\sim \quad 540 \\
\sim 500 \\
\sim 2,400\end{array}$ & $\begin{array}{r}1,480 \\
1,500 \\
500 \\
1,500 \\
1,500\end{array}$ & $\begin{array}{r}232 \\
72 \\
428 \\
197 \\
21.5\end{array}$ & $\begin{array}{c}309 \\
113 \\
856 \\
227 \\
52.5\end{array}$ & $\begin{array}{c}4.9 \times 10^{17} \\
6.6 \\
4.0 \\
4.0 \\
3.8\end{array}$ & $\begin{array}{c}1.03 \times 10^{18} \\
6.5 \\
(0.5) \\
0.85 \\
6.3\end{array}$ & $\begin{array}{l}4 \\
4 \\
4 \\
4 \\
2\end{array}$ \\
\hline $\begin{array}{l}06 \\
07 \\
08 \\
09 \\
10\end{array}$ & $\begin{array}{c}56.9 \\
188 \\
188 \\
72.9 \\
72.9\end{array}$ & $\begin{array}{l}68.06^{\mathrm{b}} \\
27.02^{\mathrm{a}} \\
27.25^{\mathrm{a}} \\
42.90^{\mathrm{b}} \\
42.5^{\mathrm{b}}\end{array}$ & $\begin{array}{c}100.38 \\
32.4 \\
32.2 \\
52.6 \\
65.9\end{array}$ & $\begin{array}{r}\sim 2,400 \\
\sim 4,600 \\
\sim 4,200 \\
\sim 2,500 \\
\sim 5,000\end{array}$ & $\begin{array}{r}1,510 \\
1,660 \\
1,570 \\
1,510 \\
570\end{array}$ & $\begin{array}{l}22.84 \\
3.894 \\
3.1 \\
6.4 \\
6.62\end{array}$ & $\begin{array}{c}51 \\
7 \\
6.5 \\
15 \\
100\end{array}$ & $\begin{array}{l}3.6 \\
3.1 \\
2.7 \\
2.9 \\
7.0\end{array}$ & $\begin{array}{c}6.7 \\
124 \\
340 \\
27 \\
22\end{array}$ & $\begin{array}{l}2 \\
2 \\
1 \\
1 \\
1\end{array}$ \\
\hline $\begin{array}{l}11 \\
12 \\
13 \\
14 \\
15\end{array}$ & $\begin{array}{c}357 \\
78.5 \\
72.5 \\
72.5 \\
76.6\end{array}$ & $\begin{array}{l}28.94^{\mathrm{a})} \\
43.53^{\mathrm{b})} \\
48.90^{\mathrm{b})} \\
44.40^{\mathrm{a})} \\
41.15^{\mathrm{c})}\end{array}$ & $\begin{array}{l}36.4 \\
61.53 \\
69.24 \\
66.40 \\
65.40\end{array}$ & $\begin{array}{r}\sim 5,600 \\
\sim 4,200 \\
\sim 4,100 \\
\sim 4,800 \\
\sim 4,200\end{array}$ & $\begin{array}{r}1,610 \\
100 \\
1,430 \\
555 \\
1,505\end{array}$ & \begin{tabular}{r}
\multicolumn{1}{c}{7.7} \\
65 \\
7.47 \\
12.02 \\
3.96
\end{tabular} & $\begin{array}{l}11.3 \\
436 \\
33.7 \\
96.2 \\
39\end{array}$ & $\begin{array}{l}0.9 \\
4.8 \\
4.6 \\
5.8 \\
5.6\end{array}$ & $\begin{array}{c}900 \\
0.99 \\
53 \\
4.5 \\
11.4\end{array}$ & $\begin{array}{l}1 \\
1 \\
1 \\
1 \\
1\end{array}$ \\
\hline $\begin{array}{l}16 \\
17 \\
18 \\
19\end{array}$ & $\begin{array}{l}76.6 \\
74.1 \\
74.1 \\
76.4\end{array}$ & $\begin{array}{l}42.0^{\mathrm{c})} \\
41.9^{\mathrm{c}} \\
42.0^{\mathrm{c})} \\
41.6^{\mathrm{b})}\end{array}$ & $\begin{array}{r}80.0 \\
61.5 \\
101.4 \\
61.7\end{array}$ & $\begin{array}{r}\sim 7,000 \\
\sim 4,800 \\
\sim 8,000 \\
\sim 4,800\end{array}$ & $\begin{array}{l}443 \\
550 \\
102 \\
500\end{array}$ & $\begin{array}{l}11.1 \\
11.7 \\
43.8 \\
16.18\end{array}$ & $\begin{array}{r}205 \\
85 \\
1,440 \\
4.85\end{array}$ & $\begin{array}{c}9.0 \\
4.9 \\
50 \\
4.85\end{array}$ & $\begin{array}{l}1.67 \\
1.98 \\
0.64 \\
6.7\end{array}$ & $\begin{array}{l}1 \\
1 \\
2 \\
2\end{array}$ \\
\hline
\end{tabular}

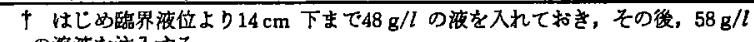
の溶液を注入する。

†十 液位が驅界液位に達した瞬間を時間の原点とする。

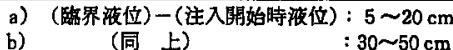
tt† ${ }^{143} \mathrm{Ce} な と ゙$ 放射化学分析により蛟正する。

c）一たん臨界を保持してから注入開始。 
ン計算機が用いられ，1 msec 当り 20 点のサンプリン グが可能であり，また特殊グローブ・ボックス内の上部 に据光付けた工業用テレビにより臨界暴走の模様がヴ イデオ記録されている。今までの実験に共通して見ら れた点としては，

(1) 最初の出力ピークは全溶液の注入が終了する 前に起った。
（2）全積算出力は全添加超過反応度, 反応度添加 速度括よび初期中性子源の強度(溶液の初期の 状態などによってきまるが, 第 1 の因子の影響 が最も支配的である。

（3）出力上昇開始後 $3 \mathrm{~min}$ 間の積算出力はいす゚れ の場合も5 $5 \times 10^{17}$ fiss. 以下であった。

（東大 清瀬量平 抄訳） 